\title{
Analisis Kegagalan Program Nasional Pemberdayaan Masyarakat dalam Membangun Kemandirian Masyarakat Miskin (Studi Kasus di Provinsi Daerah Istimewa Yogyakarta, Jawa Tengah, dan Jawa Timur)
}

\author{
An Analysis of the Failure of National Program For Community Empowerment \\ in Building the Poor Community's Independency \\ (A Case Study in the Province of Yogyakarta, Central Java, and East Java Provinces)
}

\author{
Azis Muslim ${ }^{1}$
}

${ }^{1}$ Fakultas Dakwah dan Komunikasi, Universitas Islam Negeri Sunan Kalijaga, Yogyakarta

\begin{abstract}
Poverty is a global issue that every country should solve. In Indonesia, poverty alleviation has been conducted by the government through some programs, including the National Program for Community Empowerment. This program lasted for a sufficiently long time before it was finally ended because it was considered as a failure in building the independency of poor people. This study aimed to explore the factor causing the failure. This study uses a qualitative approach. The data was collected by observation, anindepth interview, and a documentation technique. The study resultshowed that the failure of National Program for Community Empowerment in building the independency of poor people was due to two factors: facilitator's poor performance and stakeholders 'misunderstanding of the objective of National Program for Community Empowerment. The poor performance of the facilitator could be seen from his/her incompliance with the programprocedure, pragmatic working by targeting the outcome, and not performing his/her role, duty and function well. Meanwhile, the stakeholders' misunderstanding of the objective of National Program for Community Empowerment could be seen from the selection of program priority not in line with the poor people's interest.
\end{abstract}

Keywords: Poverty alleviation, national program for community empowerment, poor community independency

\begin{abstract}
Abstrak
Kemiskinan menjadi isu global yang harus diatasi oleh setiap negara. Di Indonesia, penanganan masalah kemiskinan telah dilakukan oleh pemerintah melalui beberapa program, diantaranya adalah Program Nasional Pemberdayaan Masyarakat (PNPM). Program ini berjalan cukup lama sebelum akhirnya ditutup karena dianggap gagal dalam membangun kemandirian masyarakat miskin. Tujuan penelitian ini adalah menggali faktor penyebab kegagalannya. Penelitian dilakukan dengan pendekatan kualitatif. Data dikumpulkan dengan observasi, wawancara, dan dokumentasi. Hasilnya menunjukkan bahwa kegagalan PNPM dalam membangun kemandirian masyarakat miskin disebabkan oleh dua faktor, yaitu buruknya kinerja fasilitator dan kesalahan stakeholders memahami tujuan PNPM. Buruknya kinerja fasilitator terlihat pada ketidak-patuhannya dalam menjalankan prosedur program, bekerja secara pragmatis dengan mengejar hasil, dan tidak menjalankan peran, tugas, dan fungsinya dengan baik. Sementara, kesalahan stakeholders memahami tujuan PNPM tampak pada pemilihan prioritas program yang tidak berpihak pada kepentingan masyarakat miskin.
\end{abstract}

Kata kunci: Pengentasan kemiskinan, program nasional pemberdayaan masyarakat, kemandirian masyarakat miskin

\section{Pendahuluan}

September 2000, Perserikatan Bangsa-Bangsa menyepakati agenda pembangunan global yang dikenal dengan Milenium Development Goals (MDGs). MDGs merupakan paradigma pembangunan yang meliputi pengentasan kemiskinan dan pemberantasan kelaparan, pemberdayaan perempuan dan kesetaraan gender, pemberantasan buta huruf, pengurangan kematian anak, peningkatan kesehatan ibu, pemanfaatan dan pemeliharaan lingkungan yang berkesinambungan, pemberantasan penyakit HIV/AIDS dan penyakit menular lainnya, dan pengembangan kerja sama global untuk pembangunan. Dari delapan agenda tersebut ada satu agenda yang harus diselesaikan atau dituntaskan pada tahun 2015, yaitu pengentasan kemiskinan dan pemberantasan kelaparan. Ini artinya dalam jangka waktu 15 tahun setiap pemimpin negara siap mengatasi masalah kemiskinan dan kelaparan, sehingga tidak ada lagi warga atau masyarakat yang menderita masalah

\footnotetext{
${ }^{1}$ Korespondensi penulis

E-mail: muslimtenan@gmail.com
} 
tersebut pada tahun 2015.

Setelah program MDGs berjalan hampir 15 tahun, fakta menunjukkan bahwa jumlah masyarakat miskin di Indonesia belum mengalami perubahan secara signifikan. Badan Pusat Statistik mencatat angka kemiskinan di Indonesia masih mencapai 28.553.930 orang pada tahun 2013. Angka ini mengalami penurunan sekitar $0,028 \%$ pada tahun 2014 yang mencapai 27.727 .780 orang. Namun demikian, di tahun 2015 angkanya mengalami kenaikan kembali, yaitu 28.513.570 orang atau naik sekitar 0,027 \% (BPS, 2016). Data ini membuktikan bahwa upaya pengentasan kemiskinan yang dilakukan di Indonesia belum sesuai dengan yang diharapkan. Meskipun, upaya yang dilakukan pemerintah Indonesia untuk mengatasi permasalahan ini sudah banyak, yaitu di antaranya adalah melalui Program Nasional Pemberdayaan Masyarakat (PNPM).

PNPM merupakan program pemberdayaan masyarakat yang dideklarasikan pada tahun 2006 . Program ini merupakan kelanjutan dari program pengentasan kemiskinan yang telah dijalankan sebelumnya. Pada tahun 1998, Presiden Republik Indonesia membentuk Gerakan Terpadu Pengentasan Kemiskinan untuk menanggulangi masalah kemiskinan melalui instruksi Nomor 21 Tahun 1998. Program ini dinamai dengan Program Pengembangan Kecamatan (P2K). Pada tahun 2006, Presiden mengganti nama P2K menjadi PNPM untuk memperluas cakupannya.

Dengan nama PNPM lingkup kegiatannya bertambah menjadi penanggulangan kemiskinan dan perluasan kesempatan kerja. Pada tahun 2007, Presiden menyempurnakan nama PNPM menjadi PNPM Mandiri untuk memperluas jangkauannya. Sejak saat itu, PNPM Mandiri dibagi menjadi PNPM Mandiri Pedesaan untuk menjangkau pengentasan kemiskinan dan perluasan kesempatan kerja di wilayah kabupaten, PNPM Mandiri Perkotaan untuk menjangkau pengentasan kemiskinan dan perluasan kesempatan kerja di wilayah kota madya, PNPM Mandiri Daerah Tertinggal dan Khusus untuk menjangkau pengentasan kemiskinan dan perluasan kesempatan kerja di daerah tersebut, dan PNPM Mandiri Infrastruktur Sosial Ekonomi Wilayah untuk menangani masalah infrastruktur sosial ekonomi. Prinsip yang ditegakkan PNPM Mandiri adalah pembangunan yang berpusat pada manusia. Karena itu, program PNPM Mandiri ini diharapkan mampu menjadi program pembangunan yang dapat diakses oleh seluruh lapisan masyarakat secara adil dan merata, dan mampu membangun kemandirian masyarakat miskin (Petunjuk Teknis Operasional PNPM, 2008).

PNPM Mandiri dirancang untuk mempercepat pengentasan kemiskinan dengan cara meningkatkan kemampuan kelembagaan masyarakat dan aparatur melalui pemberian modal usaha guna mengembangkan usaha ekonomi produktif dan membangun sarana dan prasarana yang mendukung kegiatan ekonomi. Program ini juga dirancang untuk memberikan kesempatan kepada masyarakat dan aparat dalam pengambilan keputusan secara demokratis, baik pada tahap perumusan atau perencanaan, implementasi, maupun monitoring dan evaluasi. Dengan melibatkan masyarakat dan aparat secara bersama-sama diharapkan program dapat dijalankan dengan baik dan optimal (Petunjuk Teknis Operasional PNPM, 2008).

Pelibatan masyarakat dalam setiap tahapan pada pengambilan keputusan sebagaimana diatur dalam Petunjuk Teknis Operasional di atas tentu dapat memberikan kepuasan tersendiri bagi masyarakat. Proses ini diharapkan mampu memberikan pengaruh positif bagi masyarakat, diantaranya masyarakat mengetahui pentingnya pembangunan di wilayahnya sendiri, masyarakat merasa memiliki hasil-hasil pembangunan, masyarakat dapat memelihara dan melestarikan hasil pembangunan, masyarakat mampu menikmati hasil pembangunan, dan yang paling penting adalah masyarakat menjadi mandiri.

Bukti empirik menunjukkan hal yang berbeda dengan harapan yang ingin dicapai. Di Kota Batu, misalnya, masyarakat sasaran yang seharusnya mandiri ternyata menjadi manja (ingin dilayani) dan ketergantungan dengan bantuan-bantuan yang diberikan. Bantuan kredit usaha yang diberikan dengan konsep "Pinjaman Bergulir" dianggap sebagai bantuan hibah yang tidak wajib dikembalikan, sehingga menjadi kredit macet dan tidak ada penyelesaiannya. Tragisnya, mereka memandang hal itu lumrah dan biasa-biasa saja (Dharmantaka, 2015). Hal serupa terjadi di Kecamatan Siak Hulu Kabupaten Kampar seperti tertuang dalam hasil penelitian Fitriani dan Rusli (2014). Lebih parah lagi, adanya pengelola yang bermental korup. Hasil penelitian Sumelung (2016) yang meneliti PNPM di Desa Boeng Kecamatan Siau Tengah Kabupaten Kepulauan Siau Tagulandang Biaro menemukan bahwa pengelola menyalahgunakan dana yang telah dikembalikan.

Di sisi lain, bantuan dana PNPM tidak mampu menumbuhkan modal sosial masyarakat sasaran, sebaliknya malah menghilangkan budaya gotong 
royong dan budaya swadaya dalam membangun wilayahnya sendiri. Hal ini tampak pada kegiatan pembangunan infrastruktur. Budaya gotong royong dan swadaya masyarakat sedikit demi sedikit mulai menghilang (Hadi et al., 2013; Nurkatamso dan Listyaningsih, 2013). Tenaga kerja dalam pembangunan infrastruktur bukan tenaga kerja suka rela lagi, tetapi tenaga kerja yang diberi gaji, meskipun mereka bekerja di wilayah atau miliknya sendiri. Karena itu, keberhasilan pembangunan infrastruktur bukan disebabkan besarnya modal sosial masyarakat, tetapi lebih disebabkan oleh besarnya dana anggaran yang dikeluarkan. Wajar, jika, Presiden Joko Widodo menutup program ini secara resmi pada 31 Desember 2014.

Pertanyaannya adalah mengapa program yang dirancang sedemikian hebat ini tidak membuahkan hasil. Hal ini tentu menarik untuk dikaji. Agar kajian tidak melebar, maka kajian ini difokuskan pada faktor-faktor penyebab kegagalan dari PNPM dalam membangun kemandirian masyarakat. Harapannya adalah hasil dari kajian ini dapat memberikan kontribusi kepada pemerintah, khususnya, dalam menyusun dan melaksanakan program pengentasan kemiskinan.

Setiap program pembangunan pada dasarnya bertujuan meningkatkan kesejahteraan masyarakat. Kesejahteraan dapat dicapai apabila pembangunan dijalankan melalui pendekatan pemberdayaan(Muslim, 2015). Pemberdayaan yang tepat harus mampu menciptakan iklim yang dapat mengembangkan potensi masyarakat, memperkuat potensi yang dimiliki masyarakat, dan melindungi atau menjaga orang-orang yang lemah supaya tidak diekploitasi orang-orang yang kuat (Mardikanto, 2010). Karena itu, pemberdayaan masyarakat bertujuan menjadikan masyarakat mandiri dan mampu mengatasi permasalahannya sendiri, bukan menjadikan masyarakat tergantung pada pihak luar. Kenyataannya, masih banyak program-program pemberdayaan yang justru membuat masyarakat menjadi ketergantungan dan tidak mandiri (Fitriani dan Rusli, 2014; Dharmantaka, 2015).

Menurut Suyanto (2001) salah satu penyebab kegagalan membangun kemandirian masyarakat adalah suatu kesalahan dalam menemu-kenali faktor penyebab kemiskinan. Kemiskinan tidak hanya berhubungan dengan faktor ekonomi atau rendahnya pendapatan seseorang, tetapi juga menyangkut banyak faktor, seperti faktor budaya, faktor geografi dan lain sebagainya yang semuanya dapat menyebabkan upaya memandirikan masyarakat miskin menjadi tidak semudah yang direncanakan. Sementara Yasa (2008) menyebut kegagalan membangun kemandirian masyarakat karena beberapa faktor, yaitu:

1. Program pemberdayaan berkutat pada pengguliran dana. Karena prinsipnya adalah bergulir, maka nalarnya orang yang dapat mengikuti program adalah orang yang memiliki usaha produktif, sedangkan orang yang tidak memiliki usaha produktif tidak dapat mengikuti program. Padahal, kebanyakan orang miskin tidak memiliki usaha produktif, sehingga mereka tidak mungkin dapat mengikuti program perguliran dana.

2. Terbatasnya pengetahuan dan ketrampilan juga mengurangi peluang bagi orang miskin untuk dapat mengikuti perguliran dana. Karena dengan terbatasnya pengetahuan dan ketrampilan dapat berpengaruh terhadap keberhasilan program.

3. Sikap petugas lapangan yang kurang serius dalam melakukan pendataan masyarakat miskin dan menghasilkan data yang tidak valid. Hal ini menjadikan data rujukan yang dijadikan acuhan program pemberdayaan tidak tepat, sehingga pemberdayaan tidak menyentuh sasaran, yaitu masyarakat miskin.

4. Kecenderungan memilih sasaran atau lokasi yang memungkinkan keberhasilannya tinggi, sehingga berakibat pada penentuan lokasi yang tidak tepat.

5. Mental masyarakat miskin yang cenderung menerima apa adanya menjadi penghambat program pemberdayaan.

6. Kecenderungan bentuk program yang mengarah pada pemberian 'ikan' bukan 'kail' atau mengajari cara memancing yang kurang tepat justru membuat perilaku masyarakat ingin tetap miskin agar tetap mendapat bantuan, bukan berusaha lepas dari kemiskinan.

Lippit dan Westley (1958), Mayo (1994), Mardikanto (2010), dan Muslim (2012) menambahkan bahwa kegagalan dalam membangun kemandirian masyarakat sering disebabkan oleh kinerja fasilitator yang tidak profesional dan kurang handal. Membangun kemandirian adalah proses yang melelahkan karena membutuhkan tenaga, pikiran dan waktu yang cukup panjang. Karena itu, kegiatan ini membutuhkan tenaga fasilitator yang profesional dan handal supaya dapat menjalankan kegiatannya, sehingga pemberdayaan dalam rangka membangun kemandirian dapat berhasil sesuai dengan yang direncanakan. Fasilitator professional dan handal yang dimaksud adalah fasilitator yang mempunyai kualifikasi kepribadian, 
pengetahuan, sikap, dan ketrampilan dalam mendampingi masyarakat.

Lippit dan Westley (1958) menyatakan bahwa kegagalan atau keberhasilan fasilitator dalam menjalankan program pemberdayaan sangat ditentukan oleh kepribadian yang tercermin pada penampilannya saat pertama kali berhadapan dengan masyarakat sasaran. Karena itu, menurut Mardikanto (2010) agar program pemberdayaan berhasil, maka fasilitator hendaknya memiliki kualifikasi kepribadian sebagai berikut:

1. Menarik penampilannya dan tidak sombong atau tidak angkuh.

2. Bersedia bergaul, menjalin kerjasama, dan tinggal bersama masyarakat sasaran.

3. Mudah menyesuaikan diri dengan lingkungan setempat, baik lingkungan fisik, pekerjaan, maupun sosial.

4. Dapat meyakinkan masyarakat bahwa dirinya adalah pendamping yang memiliki kemampuan untuk menjalankan tugas.

5. Bersedia membantu masyarakat dalammenganalisis dan memecahkan masalah yang dihadapi.

Selain kepribadian, kualifikasi pengetahuan seorang fasilitator juga menjadi faktor penentu keberhasilan atau kegagalannya dalam membangun kemandirian masyarakat. Muslim (2012) menjelaskan bahwa seorang fasilitator dituntut memiliki kualifikasi pengetahuan, baik secara teoritis maupun praktis, agar program yang dijalankan mencapai target yang diharapkan. Kualifikasi pengetahuan itu meliputi:

1. Isi, fungsi, dan manfaat, serta nilai-nilai yang dikandung dari sebuah inovasi yang sedang disampaikan.

2. Keadaan latar belakang sosial budaya masyarakat sasaran terutama yang berkaitan dengan bahasa, agama, dan adat istiadat.

3. Hal-hal yang dapat menyebabkan masyarakat menginginkan atau tidak menginginkan terjadinya sebuah perubahan atau hal-hal yang dapat menyebabkan masyarakat menerima atau menolak sebuah inovasi.

Kualifikasi sikap fasilitator juga dapat menentukan berhasil atau gagalnya upaya membangun kemandirian masyarakat. Menurut Muslim (2012) kualifikasi sikap yang wajib dimiliki oleh seorang fasilitator adalah:

1. Bangga terhadap profesinya, menghayati, dan merasakan bahwa kehadirannya dalam menjalankan tugas sangat dibutuhkan masyarakat sasaran.

2. Meyakini bahwa inovasi yang disampaikan memiliki peluang keberhasilan, memberikan kemanfaatan, tidak bertentangan dengan nilainilai sosial budaya masyarakat, dan benar-benar dibutuhkan oleh masyarakat sasarannya.

3. Mencintai masyarakat sasaran yang diwujudkan dengan kesiap-sediaan membantu dan atau menjalankan kegiatan-kegiatan demi berlangsungnya perubahan kehidupan masyarakat sasaran.

Kualifikasi fasilitator lainnya yang dapat menentukan berhasil atau gagalnya upaya membangun kemandirianmasyarakat adalahkualifikasi ketrampilan. Mayo (1994) menyatakan bahwa seorang fasilitator dituntut untuk menguasai ketrampilan-ketrampilan tertentu agar program pemberdayaan yang dijalankan tidak gagal. Ketrampilan-ketrampilan itu adalah:

1. Ketrampilan menjalin relasi.

2. Ketrampilan melakukan assessment.

3. Ketrampilan melakukan riset.

4. Ketrampilan melakukan dinamika kelompok.

5. Ketrampilan bernegosiasi.

6. Ketrampilan berkomunikasi.

7. Ketrampilan melakukan konsultasi.

8. Ketrampilan manajemen, termasuk manajemen waktu dan dana.

9. Ketrampilan mencari sumber dana.

10. Ketrampilan mencatat dan menulis kasus dan laporan.

11. Ketrampilan melakukan pemantauan dan evaluasi.

Di sisi lain, Susetiawan (2016) menyatakan

bahwa kegagalan program pemberdayaan masyarakat dalam membangun kemandirian disebabkan oleh perilaku dan mental fasilitator yang tidak sejalan dengan konsep, prinsip, dan filosofi pemberdayaan. Menurutnya banyak fasilitator yang berpikir dan berbicara mengenai pemberdayaan, namun tindakannya masih menganggap masyarakat sasaran sebagai masyarakat yang lemah, bodoh, dan harus didampingi terus, sehingga masyarakat menjadi ketergantungan. Hal ini diperparah dengan sering dilupakannya metode dan teknik pemberdayaan dengan mengedepankan kedermawanan (filantrofi) dalam proses mendorong perubahan sosial. Selain itu, fasilitator juga menggantungkan hidupnya dengan dana bantuan dari pihak luar dan masyarakat miskin dijadikan barang dagangan, sehingga jika bantuan terputus, maka pemberdayaan berhenti. Fenomena ini ternyata sejalan dengan kondisi masyarakat yang suka menerima pemberian materi dari pada harus bekerja 
keras.

\section{Metode Penelitian}

Penelitian ini dilakukan dengan pendekatan kualitatif fenomenologis. Artinya, peneliti berusaha memahami fenomena-fenomena sosial yang menjadi penyebab gagalnya sebuah program pemberdayaan dalam membangun kemandirian masyarakat dengan mendiskripsikan secara kualitatif. Alasan penggunaan pendekatan ini terhadap permasalahan yang dikaji adalah pertama, dapat menjadi sumber deskripsi dan eksplanasi yang lebih berakar. Kedua, mampu membangun hubungan yang lebih dekat antara peneliti dengan informan yang menjadi sasaran kajian. Ketiga, memberikan peluang bagi peneliti untuk mengungkapkan runtutan kejadian sosial, menilai, dan memberikan penjelasan atas hubungan sebab akibat yang terjadi pada peristiwa lokal. Keempat, memudahkan peneliti menjawab pertanyaan yang diajukan (Muslim, 2014).

PNPM adalah program nasional yang lokasinya tersebar di seluruh Indonesia. Mengingat waktu, biaya, dan tenaga, peneliti hanya mengambil kasus pada tiga wilayah saja, yaitu Provinsi Daerah Istimewa Yogyakarta, Jawa Tengah, dan Jawa Timur. Alasannya adalah masyarakat miskin di tiga provinsi ini memiliki indeks keparahan yang tinggi. Pemilihan sampel dilakukan secara purposive dengan teknik berdasarkan kriteria (Patton, 2009). Adapun kriterianya adalah kabupaten yang masuk pada indek keparahan kemiskinan di atas 0,5\% pada tahun 2014 . Berdasarkan kriteria itu ada 27 kabupaten/kota yang dijadikan sampel dari 78 kabupaten/kota yang ada di tiga provinsi tersebut. Rinciannya adalah 13 kabupaten/ kota di Provinsi Jawa Timur, 11 kabupaten/kota di Provinsi Jawa Tengah, dan 3 kabupaten di Provinsi Daerah Istimewa Yogyakarta.

Informan utama dalam penelitian ini adalah pejabat pemerintah setempat yang terlibat langsung, fasilitator, dan masyarakat penerima program, sedangkan informan pendukungnya adalah tokohtokoh masyarakat setempat dan masyarakat non penerima program. Teknik penentuan informan dilakukan dengan bola salju. Besarnya jumlah informan utama dan pendukung ditetapkan berdasarkan kejenuhan informasi yang diperoleh (Moleong, 2006). Artinya, jika informasi baru yang diharapkan muncul dari informan baru tidak diperoleh atau tidak muncul, maka penarikan sampel diakhiri. Data dikumpulkan dengan menggunakan observasi, wawancara, dan dokumentasi. Teknik validitas data dilakukan melalui triangulasi, dan teknik analisis data menggunakan analisis interaktif dari Miles dan Huberman.

\section{Hasil dan Pembahasan}

Berdasarkan buku pedoman, pelaksanaan program PNPM Mandiri harus dijalankan secara partisipatif dari bawah. Program dimulai dari perencanaan, pelaksanaan, dan pelestarian kegiatan. Sebelum memulai perencanaan, hal yang harus dijalankan adalah melakukan orientasi atau pengenalan kondisi yang ada di wilayah sasaran program. Diantaranya adalah mengidentifikasi potensi dan sumber daya yang mendukung pelaksanaan program, mengenali kemiskinan dan faktor-faktor penyebabnya, dan sosialisasi program secara informal kepada masyarakat untuk menarik partisipasinya (Tim Pengendali PNPM Mandiri, 2007). Di lapangan proses tersebut ada yang tidak dijalankan dan ada yang dijalankan sebagaimana mestinya. Beberapa informan di lokasi yang dijadikan sampel menyatakan bahwa mereka lebih memilih memanfaatkan data yang tersedia di kantor desa dari pada menggali data baru untuk menyusun rencana kerja karena prosesnya lebih cepat. Hal ini seperti diungkapkan oleh ketua Badan Keswadayaan Masyarakat (BKM) Taman Sejahtera yang menyatakan bahwa "untuk merencanakan program PNPM, kita sepakat menggunakan rencana strategi desa yang sudah tersedia". Sementara, sebagian yang lain menyatakan sebaliknya, yaitu lebih memilih melaksanakan prosedur yang ditetapkan meskipun prosesnya memakan waktu yang panjang.

Perilaku fasilitator yang mengambil jalan pintas ini menunjukkan bahwa kinerjanya masih jelek. Mereka tidak menyadari pentingnya memahami latar belakang dan keadaan masyarakat sasaran. Ini berarti mereka tidak memiliki kualifikasi pengetahuan yang baik dalam melakukan pemberdayaan masyarakat (Muslim, 2012). Di samping itu, mereka tidak menyadari bahwa pemberdayaan merupakan sebuah "proses menjadi" yang membutuhkan waktu yang cukup panjang dan tenaga yang cukup melelahkan, bukan "sekedar hasil" yang dapat dilakukan dengan cepat dan tergesa-gesa.

Di sisi lain, proses perencanaan program PNPM ada yang dilakukan sesuai prosedur dan ada yang dilakukan di luar prosedur. Proses perencanaan di luar prosedur sering dilakukan oleh Lembaga 
Pemberdayaan Masyarakat Desa (LPMD). Lembaga yang anggotanya terdiri dari kepala dusun (Kadus), tokoh masyarakat, dan ketua rukun tetangga (RT) ini berembuk secara khusus tanpa kehadiran fasilitator. Keputusan yang dihasilkan dari forum ini, kemudian dibawa oleh masing-masing ketua RT untuk disosialisasikan kepada warganya melalui forum rapat yang digelar secara rutin di tingkat RT. Pada pertemuan ini, warga diminta persetujuan dan kesediaan berpartisipasi baik tenaga maupun pendanaan. Penolakan warga terhadap program yang telah diputuskan LPMD dipandang tabu. Fasilitator menerima proses ini karena menganggap telah sesuai prosedur, yaitu perencanaan sudah berjalan dari bawah (bottom up). Hal ini seperti dituturkan oleh Sugiyanto sebagai berikut:

\section{Kalau LPMD-nya aktif, kita enak dan tidak repot. Mereka bisa membuat program sendiri tanpa harus kita dampingi. Kita cukup ketemu pengurus, siapa saja, kita beri pengertian mereka. Kalau mereka paham, mereka bisa jalan sendiri tanpa kita dampingi. Kita tinggal menerima hasil musyawarah mereka untuk dimasukkan dalam rencana program. ......Oh, itu tidak salah karena prosesnya betul-betul berjalan dari bawah.}

Proses perencanaan program sebagaimana tersebut di atas memiliki banyak kelemahan. Pertama, adanya keberpihakan pada kepentingan elit dari pada kepentingan masyarakat miskin (Tjokrowinoto, 2002). Hal ini jika tidak disadari sejak dari awal tentu dapat mengubah tujuan utama PNPM. Kedua, partisipasi yang dijalankan oleh masyarakat miskin merupakan partisipasi semu, karena mereka berpartisipasi secara terpaksa dan dipaksa (Mikkelsen, 2003). Ketiga, peran fasilitator tidak nampak, padahal fasilitator seharusnya siap sedia membantu masyarakat dalam menganalisis permasalahan dan memecahkan masalah yang dihadapi (Mardikanto, 2010).

Pada tahap pelaksanaan, program PNPM diklasifikasi dalam tiga bentuk yaitu unit pengelola lingkungan (UPL) untuk menangani masalah infrastruktur, unit pengelola sosial (UPS) untuk menangani peningkatan ketrampilan dan usaha masyarakat miskin, dan unit pengelola keuangan (UPK) untuk menangani dana operasional BKM, pelaporan keuangan, dan simpan pinjam. Alokasi dana untuk ketiga unit ini sangat timpang, yaitu $75 \%$ untuk UPL, $15 \%$ untuk UPS, dan $10 \%$ untuk UPK. Di lapangan penerapan alokasi anggaran ini tidak mengalami perubahan secara signifikan. Meskipun ada beberapa desa atau kelurahan yang menambah atau mengurangi anggaran untuk UPL menjadi lebih atau kurang dari $75 \%$, namun porsinya tetap paling tinggi.

Permasalahannya adalah program infrastruktur yang dibangun sering tidak tepat sasaran untuk pengentasan masalah kemiskinan. Sebagai contoh, hampir di setiap desa atau kelurahan mengalokasikan dana UPL untuk pembangunan jalan, saluran irigasi, gedung sekolah, dan sejenisnya. Padahal pembangunan infrastruktur seperti itu sudah ada dinas yang menanganinya. Pembangunan jalan, misalnya, sudah ditangani oleh Dinas Pekerjaan Umum, pembangunan gedung sekolah ditangani oleh Dinas Pendidikan. Hal ini menunjukkan tidak adanya koordinasi antara pengelola PNPM dengan dinas-dinas tersebut. Di sisi lain, pembangunan infrastruktur seperti itu jelas tidak berkaitan langsung dengan persoalan orang miskin. Mestinya infrastruktur yang dibangun harus berhubungan langsung dengan persoalan orang miskin, misalnya pembangunan ruko untuk berdagang bagi orang miskin, pembangunan kandang kelompok dan lain sejenisnya.

Menurut Jaya (2010) kesalahan ini dapat terjadi disebabkan pertama, musyawarah yang seharusnya membuka ruang partisipasi dari orang miskin didominasi oleh kalangan elit. Kedua, perencanaan awal tidak melibatkan orang miskin, karena musyawarah hanya dilakukan oleh kadus, ketua RT dan tokoh masyarakat. Ketiga, ketidakberanian orang miskin mengeluarkan pendapat dalam forum yang dihadiri tokoh masyarakat. Keempat, fasilitator tidak mampu memberikan rangsangan, arahan, atau kritikan terhadap program yang tidak terkait dengan pengentasan kemiskinan. Kelima, tidak terpikir bahwa tujuan PNPM adalah pengentasan kemiskinan, namun yang terbayang adalah program harus muncul dari bawah.

Pelaksanaan kegiatan PNPM bidang UPS secara umum telah menyentuh sasaran, yaitu masyarakat miskin. Kegiatan seperti usaha ternak bergulir, pelatihan ternak sapi, pelatihan menjahit, pelatihan budidaya ikan, pelatihan memasak dan lain sebagainya diperuntukkan bagi peningkatan kapasitas sumber daya dari masyarakat miskin agar muncul berbagai usaha produktif di kemudian hari. Namun, apakah kegiatan itu relevan dengan 
kebutuhan masyarakat miskin?. Beberapa informan menyatakan bahwa mereka tidak mendapat tambahan pengetahuan, karena pada dasarnya mereka telah memiliki ketrampilan yang dilatihkan. Hal ini terjadi karena peserta pelatihan diambil dari orang-orang yang menekuni pekerjaan yang dilatihkan. Misalnya, pelatihan menjahit ditujukan bagi ibu-ibu yang memiliki pengalaman menjahit. Pelatihan budidaya ikan ditujukan bagi orang-orang yang memiliki kolam ikan, dan lain sebagainya. Peserta pelatihan ditunjuk oleh kadus atas permintaan BKM, bukan berdasarkan pengumuman secara terbuka. Karena itu, tidak aneh ada peserta yang menyatakan bahwa kesediaannya hadir pada kegiatan ini karena mendapat uang saku, bukan dorongan mendapat pengetahuan.

Kondisi di atas tentu berdampak pada keberlanjutan program. Sudah dapat dipastikan bahwa peserta yang tidak serius mengikuti kegiatan akan berakhir sampai di situ saja, sedangkan bagi yang serius mengikuti kegiatan tentu masih membutuhkan bimbingan untuk dapat membuka usaha baru. Sayangnya, di beberapa lokasi yang mengadakan kegiatan pelatihan tersebut belum ada atau bahkan tidak pernah ada kegiatan tindak lanjut. Faktor penyebabnya adalah kurangnya fasilitas penunjang, baik pendampingan maupun sumber dana untuk membuka usaha. Hal ini terjadi karena kemampuan dan ketrampilan fasilitator yang rendah, serta penganggaran kegiatan yang timpang dan cenderung pada kegiatan fisik dari pada kegiatan yang mengarah pada pengentasan kemiskinan.

Di sisi lain, kegiatan usaha ternak bergulir juga sering meleset dan tidak tepat sasaran. Beberapa informan mengaku ternak pemberian BKM habis dijual dengan alasan yang bermacam-macam, diantaranya ada yang menyatakan karena adanya kebutuhan mendesak, menambah beli kendaraan, atau tidak dapat merawat. Bejo, misalnya, menyatakan tidak memiliki waktu untuk mencarikan makan ternaknya karena harus mengerjakan tugas pokoknya. Beliau terpaksa harus menjual ternak pemberian BKM karena tidak sempat mencari rumput akibat kelelahan bekerja di sekolah sebagai tukang kebun. Berdasarkan pengakuannya, bapak dari tiga orang anak ini, menyatakan tidak pernah mengajukan permintaan ternak kepada BKM. Beliau mengaku tiba-tiba dipanggil ke kantor BKM untuk menerima pemberian kambing. Anehnya lagi, dana dari hasil penjualan ternaknya tidak pernah diminta oleh BKM untuk digulirkan ke tempat lain. Padahal akad pemberiannya adalah dana bergulir.
Kesalahan dalam menunjuk atau memilih orang miskin seperti tersebut di atas akan terus terjadi selama kinerja fasilitatornya rendah. Rendahnya kinerja fasilitator pada kasus di atas dapat ditunjukkan dengan: pertama, keengganannya turun ke lapangan untuk memilih sasaran yang tepat (Muslim, 2012). Kedua, ketidak-sediaan bergaul, menjalin kerjasama, dan tinggal bersama masyarakat sasaran (Mardikanto 2010). Ketiga, tidak mampu merasakan bahwa kehadirannya dalam menjalankan tugas sangat dibutuhkan oleh masyarakat (Muslim, 2012). Keempat, tidak memiliki ketrampilan menjalin relasi, komunikasi, melakukan penilaian, dan melakukan pemantauan serta evaluasi (Mayo, 1994; Sapar et al., 2012; Mujiburrahmad et al., 2014). Akibatnya, kegiatan UPS yang telah dilaksanakan tidak dapat merangsang tumbuhnya usaha baru atau alih profesi dari masyarakat miskin.

Selanjutnya, pelaksanaan program PNPM bidang UPK yang bersentuhan langsung dengan masyarakat miskin adalah simpan pinjam. Asumsi dasarnya adalah pertama, setelah masyarakat miskin dilatih atau diberi ketrampilan, mereka perlu disediakan modal untuk membuka usaha. Kedua, masyarakat miskin sulit mendapatkan kredit usaha di lembaga perbankan, karena ketiadaan agunan yang dimiliki. Kenyataan di lapangan ditemukan bahwa simpan pinjam dari alokasi dana UPK tidak hanya dimanfaatkan oleh orang miskin, tetapi ada pegawai negeri sipil (PNS) dan tokoh masyarakat yang ikut menjadi anggota. Hal ini selain disebabkan oleh pengurus BKM tidak selektif dalam menentukan anggota, juga karena pengurus BKM menghendaki dananya segera terserap.

Mudahnya meminjam uang di BKM mendorong hampir setiap orang, baik yang mempunyai usaha maupun yang tidak mempunyai usaha, tergiur untuk memanfaatkan, meskipun jumlah pinjamannya tidak besar. Mereka datang berbondong-bondong ke BKM untuk meminjam uang. Dampak negatifnya adalah terjadi kredit macet, karena sebagian peminjam menggunakan uangnya untuk kebutuhan konsumtif bukan untuk modal usaha. Kondisi ini diperparah lagi dengan cara berpikir sebagian peminjam yang tidak percaya dengan para pengelola negara yang korup, sehingga mereka mengganggap tidak ada gunanya mengembalikan pinjaman kalau akhirnya dikorupsi oleh para pejabat. Karena itu, tidak heran jika hampir di setiap BKM ada kredit macet.

Kejadian itu semakin menguatkan temuan 
Dharmantaka (2015) yang meneliti program yang sama di Kota Batu. Terjadinya kredit macet disebabkan oleh pencatutan nama, yaitu menggunakan identitas orang miskin untuk meminjam dana, dan pelanggaran aturan main program. Pelanggaran aturan main jika dikaitkan dengan kasus di atas adalah masuknya PNS dan tokoh masyarakat sebagai anggota di koperasi simpan pinjam. Padahal, yang seharusnya menjadi anggota koperasi simpan pinjam adalah masyarakat miskin.

Sesungguhnya, apakah masyarakat miskin membutuhkan modal usaha?. Mungkin yang dibutuhkan orang miskin bukan bantuan modal usaha, tetapi bantuan pendampingan usaha, seperti bantuan pemasaran hasil produksi. Beberapa informan menyatakan bahwa mereka membutuhkan pendampingan mengenai cara memasarkan produk usahanya, bukan modal usaha. Menurut mereka jumlah pinjaman yang kecil tidak mungkin dapat digunakan untuk meningkatkan produksinya. Sebagian lagi ada yang menyatakan lebih senang diberi fasilitas tempat usaha yang dapat digunakan untuk memasarkan hasil usaha dari pada dipinjami modal usaha. Hal ini seperti dituturkan oleh Atik sebagai berikut: "bagi saya modal sudah cukup karena usaha saya masih kecil. Kalau ada yang mau membantu, saya lebih senang dibantu memasarkan, sehingga cepat laku dari pada dipinjami tambahan modal'.

Pandangan bahwa orang miskin selalu kekurangan modal usaha ternyata tidak mesti benar. Karena itu, indikator keberhasilan program simpan pinjam yang diukur dengan keterserapan dana jelas salah. Terjadinya kredit macet dan ketidakcermatan dalam menentukan kebutuhan orang miskin ini sesungguhnya bermula dari kecerobohan dan kesalahan fasilitator dalam mengenali dan menemukan faktor penyebab kemiskinan (Suyanto, 2001), karena mereka tidak menjalankan prosedur yang sudah diatur dalam buku panduan (Tim Pengendali PNPM Mandiri, 2007).

Pada tahap pelestarian kegiatan PNPM, di lapangan ditemukan kesadaran masyarakat mulai tumbuh untuk memelihara dan melestarikan hasilhasil kegiatan yang dapat dinikmati bersama. Pemeliharaan jalan, saluran irigasi, gedung Pendidikan Anak Usia Dini (PAUD), misalnya, dilakukan secara gotong royong. Sementara, kegiatan-kegiatan yang seharusnya dinikmati oleh masyarakat miskin kurang mendapat perhatian dalam pelestariannya. Kegiatan ternak bergulir, misalnya, tidak mendapat perhatian yang serius baik dari masyarakat umum, kalangan elit desa atau dusun, bahkan fasilitatornya sendiri. Hal ini disebabkan tujuan utama PNPM tidak terpahami dengan baik. Mereka lupa atau memang tidak paham bahwa tujuan utama PNPM adalah pemberdayaan masyarakat miskin bukan pembangunan. Mereka juga lupa bahwa tujuan akhir yang ingin dicapai PNPM adalah penurunan angka kemiskinan dan peningkatan kesejahteraan masyarakat bukan jumlah dan kualitas infrastruktur umum yang sudah dibangun.

\section{Kesimpulan}

Faktor penyebab utama kegagalan PNPM dalam membangun kemandirian masyarakat miskin terletak pada buruknya kinerja fasilitator dan kesalahan stakeholders memahami tujuan PNPM. Buruknya kinerja fasilitator terlihat dari ketidaksediaan melaksanakan program sesuai prosedur yang telah digariskan, bekerja secara pragmatis dengan mengedepankan hasil dari pada proses, dan tidak menjalankan peran, tugas, dan fungsinya dengan baik sebagai pendamping masyarakat, baik dalam merencanakan, melaksanakan, maupun mengevaluasi program. Kesalahan stakeholders memahami tujuan PNPM nampak pada pemilihan prioritas program. Program-program yang dipilih cenderung mengarah pada kepentingan umum dari pada kepentingan masyarakat miskin. Pembangunan infrastruktur jalan, gedung sekolah, saluran irigasi yang sering diprioritaskan merupakan contoh program yang diperuntukkan bagi masyarakat umum. Sementara, pembangunan kios pertokoan, outlet, atau warung yang diperuntukkan bagi masyarakat miskin untuk memasarkan usahanya belum disentuh.

\section{Daftar Pustaka}

Badan Pusat Statistik (BPS). 2016. Jumlah Penduduk Miskin Menurut Provinsi 2013-2015. [internet]. [dapat diunduh di: https://www.bps.go.id/].

Dharmantaka R. 2015. Evaluasi Pelaksanaan Pinjaman Bergulir Program Nasional Pemberdayaan Masyarakat (PNPM) Mandiri di Kota Batu. Jurnal Ilmiah Mahasiswa FEB. 3 (1): 3-13.

Fitriani, Rusli Z. 2014. Evaluasi Pelaksanaan Program Nasional Pemberdayaan Masyarakat (PNPM) Mandiri di Kecamatan Siak Hulu Kabupaten Kampar. Jurnal Online Mahasiswa Bidang Ilmu Sosial dan Politik. 1 (1): 1-15.

Hadi AR, Effendi I, Hasanuddin T. 2013. Peranan 
Kader Pemberdayaan Masyarakat Desa (KPMD) dan Partisipasi Masyarakat pada Program Nasional Pemberdayaan Masyarakat Mandiri Pedesaan (PNPM-MP) di Kecamatan Wonosobo Kabupaten Tanggamus. Jurnal IlmuIlmu Agribisnis. 1 (1): 66-72.

Jaya PHI. 2010. Sesat Pikir Pengentasan Kemiskinan: Kasus PNPM Mandiri Sebagai Model Nasional Pengentasan Kemiskinan, Yogyakarta (ID): MU3 Communications.

Lippit RJW, Westley B. 1958. The Dynamics of Planned Change. New York: Harcourt, Brace and World, Inc.

Mardikanto T. 2010. Konsep-Konsep Pemberdayaan Masyarakat: Acuan bagi Aparat Birokrasi, Akademisi, Praktisi dan Peminat/Pemerhati Pemberdayaan Masyarakat. Surakarta (ID): Fakultas Pertanian Universitas Sebelas Maret.

Mayo V. 1994. Community Worker, in Practising Sosial Work. editor Christopher Hanvey and Terry Philpot, London (UK): Routledge.

Mikkelsen B. 2003. Metode Penelitian Partisipatoris dan Upaya-upaya Pemberdayaan: Sebuah Buku Pegangan bagi Para Praktisi Lapangan, Terjemahan Matheos Nalle, Jakarta (ID): Yayasan Obor Indonesia. Moleong LJ. 2006. Metodologi Penelitian Kualitatif. Bandung (ID): Remaja Rosdakarya.

Mujiburrahmad, Muljono P, Sadono D. 2014. Kinerja Penyuluh Pertanian di Kabupaten Pidie Provinsi Aceh dalam Melaksanakan Tugas dan Fungsinya. Jurnal Penyuluhan. 10 (2): 141-150.

Muslim A. 2012. Dasar-Dasar Pengembangan Masyarakat. Yogyakarta: Samudra Biru.

Muslim A. 2014. Model Pemberdayaan Ekonomi Masyarakat Miskin Perkotaan Berbasis Tanggung Jawab Sosial Masjid. [Disertasi]. Surakarta: Universitas Sebelas Maret.

Muslim A. 2015. A Model of Job Opportunity Creation through Basic Skill Empowerment for Housewives. Jurnal Komunitas. 7 (2): 166-175.
Muslim A. 2015. A Model of Shodaqoh-Based Waste Management. Environmental Management and Sustainable Development. 4 (1): 164-179.

Nurkatamso A, Listyaningsih U. 2013. Tingkat Partisipasi Masyarakat dalam Program Fisik Program Nasional Pemberdayaan Masyarakat Mandiri Pedesaan di Kecamatan Nanggulan Kabupaten Kulon Progo, Yogyakarta(ID): Jurnal Bumi Indonesia. 2 (2): 63-67.

Patton MQ. 2009. Metode Evaluasi Kualitatif. (Terjemah). Yogyakarta (ID): Pustaka Pelajar.

Petunjuk Teknis Operasional PNPM Tahun 2008.

Sapar, Jahi A, Asngari PS, Amiruddin, Purnaba IGP. 2012. Kinerja Penyuluh Pertanian dan Dampaknya pada Kompetensi Petani Kakao di Empat Wilayah Sulawesi Selatan. Jurnal Penyuluhan. 8 (1): 29-41.

Sumelung RM. 2016. Evaluasi Program Nasional Pemberdayaan Masyarakat Mandiri Pedesaan dalam Meningkatkan Kesejahteraan Masyarakat. Jurnal Eksekutif. 1 (7): 1-7.

Susetiawan. 2016. Peningkatan Kualitas Masyarakat Melalui Cara Pemberdayaan: Dalam PerspektifPembangunan Sosial. Makalah disampaikan pada Seminar Nasional di Fakultas Ilmu Dakwah dan Ilmu Komunikasi Universitas Islam Negeri Syarif Hidayatullah Jakarta pada tanggal 26 Mei 2016.

Suyanto B. 2001. Kemiskinan dan Pemberdayaan Masyarakat Miskin. Masyarakat, Kebudayaan dan Politik. 14 (4): 25-42.

Tim Pengendali PNPM Mandiri. 2007. Pedoman Umum PNPM Mandiri, Jakarta (ID): Tim Pengendali PNPM Mandiri-Tim Koordinasi Penanggulangan Kemiskinan.

Tjokrowinoto M. 2002. Pembangunan Dilema dan Tantangan, Yogyakarta (ID): Pustaka Pelajar.

Yasa IGWM. 2008. Penanggulangan Kemiskinan Berbasis Partisipasi Masyarakat di Provinsi Bali. Input: Jurnal Ekonomi dan Sosial. 1 (2): 86-91. 